\title{
The Artificial Bowel Sphincter in the Treatment of Fecal Incontinence, Long-term Complications
}

Citation for published version (APA):

van der Wilt, A. A., Breukink, S. O., Sturkenboom, R., Stassen, L. P., Baeten, C. G., \& Melenhorst, J. (2020). The Artificial Bowel Sphincter in the Treatment of Fecal Incontinence, Long-term Complications. Diseases of the Colon \& Rectum, 63(8), 1134-1141. https://doi.org/10.1097/DCR.0000000000001683

Document status and date:

Published: 01/08/2020

DOI:

10.1097/DCR.0000000000001683

Document Version:

Publisher's PDF, also known as Version of record

Document license:

Taverne

Please check the document version of this publication:

- A submitted manuscript is the version of the article upon submission and before peer-review. There can be important differences between the submitted version and the official published version of record.

People interested in the research are advised to contact the author for the final version of the publication, or visit the DOI to the publisher's website.

- The final author version and the galley proof are versions of the publication after peer review.

- The final published version features the final layout of the paper including the volume, issue and page numbers.

Link to publication

\footnotetext{
General rights rights.

- You may freely distribute the URL identifying the publication in the public portal. please follow below link for the End User Agreement:

www.umlib.nl/taverne-license

Take down policy

If you believe that this document breaches copyright please contact us at:

repository@maastrichtuniversity.nl

providing details and we will investigate your claim.
}

Copyright and moral rights for the publications made accessible in the public portal are retained by the authors and/or other copyright owners and it is a condition of accessing publications that users recognise and abide by the legal requirements associated with these

- Users may download and print one copy of any publication from the public portal for the purpose of private study or research.

- You may not further distribute the material or use it for any profit-making activity or commercial gain

If the publication is distributed under the terms of Article $25 \mathrm{fa}$ of the Dutch Copyright Act, indicated by the "Taverne" license above, 


\title{
The Artificial Bowel Sphincter in the Treatment of Fecal Incontinence, Long-term Complications
}

\author{
Aart A. van der Wilt, M.D. ${ }^{1}$ Stéphanie O. Breukink, M.D., Ph.D. ${ }^{1,2,3}$ \\ Rosel Sturkenboom, M.D. ${ }^{1}$ Laurents P. Stassen, M.D., Ph.D. ${ }^{1}$ \\ Cornelius G. Baeten, M.D., Ph.D. ${ }^{1}$ Jarno Melenhorst, M.D., Ph.D. ${ }^{1,3}$ \\ 1 Maastricht University Medical Centre, Department of Surgery, Maastricht, the Netherlands \\ 2 Maastricht University Medical Centre, NUTRIM school of Nutrition and Translational Research in Metabolism, Maastricht, \\ the Netherlands \\ 3 Maastricht University Medical Centre, GROW School for Oncology and Developmental Biology, Maastricht, the Netherlands
}

\section{See "Editorial" on page 1017.}

BACKGROUND: Fecal incontinence is a common and debilitating condition, of which the prevalence increases with age. Several medical and minimally invasive treatment modalities are available. However, for patients with greater sphincter defects, these treatments are often not sufficient. For these patients, the artificial bowel sphincter could be an alternative to colostomy. The artificial bowel sphincter has proven to be effective in the short term. Less is known whether the benefits sustain over time.

OBJECTIVE: The aim of this study was to assess the longterm outcome of the artificial bowel sphincter in patients with refractory fecal incontinence.

DESIGN: A retrospective record review was conducted in conjunction with questionnaires.

SETTING: This study was conducted in a tertiary hospital setting.

MAIN OUTCOME MEASURES: The primary end point was any complication. The secondary end point was fecal loss.

PATIENTS: The patients included were adults experiencing severe fecal incontinence treated with artificial bowel sphincter, operated on between 1997 and 2014.

Funding/Support: None reported.

Financial Disclosures: None reported.

Correspondence: Aart A. van der Wilt, M.D., Maastricht University Medical Center, P. Debyelaan 25, 6202 AZ Maastricht, The Netherlands. E-mail: aartvanderwilt@hotmail.com

Dis Colon Rectum 2020; 63: 1134-1141 DOI: 10.1097/DCR.0000000000001683

(C) The ASCRS 2020
RESULTS: Sixty-three patients were included in this study. After a median follow-up of 57 months (range, 1-198), the device had been explanted in 31 patients $(49.2 \%$; $95 \%$ CI, 36.5-62.0). In total, 101 reoperations were conducted, ranging from 1 to 6 reoperations per patient. The main reasons for revision were device failure and infection. At 5 years follow-up, $80 \%$ of the cohort had experienced a complication requiring surgery. Twenty-two (35\%) patients had restored continence.

LIMITATIONS: This study was limited by its retrospective design and subjective secondary outcome.

CONCLUSION: Patients with severe end-stage fecal incontinence can benefit from artificial bowel sphincter, but this requires a large number of reoperations, and at least $20 \%$ of patients will eventually have a colostomy. Therefore, careful patient selection and the involvement of patients in decision making regarding the potential benefits and limitations of this technique are paramount. See Video Abstract at http://links.lww.com/DCR/B242.

\section{EL ESFÍNTER INTESTINAL ARTIFICIAL EN EL TRATAMIENTO DE LA INCONTINENCIA FECAL, COMPLICACIONES A LARGO PLAZO}

ANTECEDENTES: La incontinencia fecal es una condición común y debilitante, cuya prevalencia aumenta con la edad. Se encuentran disponibles varias modalidades de tratamiento médico y mínimamente invasivo. Sin embargo, para pacientes con defectos del esfínter mayores, estos tratamientos a menudo no son suficientes. Para estos pacientes, el esfínter intestinal artificial (ABS) podría ser una alternativa a la colostomía. El esfínter intestinal artificial demostró ser efectivo a corto plazo. Se sabe menos si los beneficios se mantienen a lo largo del tiempo. 
OBJETIVO: El objetivo de este estudio fue evaluar el resultado a largo plazo del esfínter intestinal artificial en pacientes con incontinencia fecal refractaria.

DISEÑO: Se realizó una revisión retrospectiva de los registros junto con los cuestionarios.

AJUSTE: Realizado en un entorno de hospital de tercel nivel.

PRINCIPALES MEDIDAS DE RESULTADO: El punto final primario fue cualquier complicación, el punto final secundario fue la pérdida fecal.

PACIENTES: Los pacientes incluidos fueron adultos que padecían incontinencia fecal severa tratados con esfínter intestinal artificial, operados entre 1997 y 2014.

RESULTADOS: Sesenta y tres pacientes fueron incluidos en este estudio. Después de una mediana de seguimiento de 57 meses (rango 1-198), el dispositivo había sido explantado en 31 pacientes (49.2\%; 95CI 36.5-62.0). En total, se realizaron 101 reoperaciones, que oscilaron de una a seis reoperaciones por paciente. Las principales razones para la revisión fueron la falla del dispositivo y la infección. A los cinco años de seguimiento, el 80\% de la cohorte había experimentado una complicación que requería cirugía. 22 pacientes habían recuperado la continencia (35\%).

LIMITACIONES: Diseño retrospectivo y resultado secundario subjetivo.

CONCLUSIÓN: Los pacientes con incontinencia fecal grave en etapa terminal pueden beneficiarse del esfínter intestinal artificial, pero esto requiere una gran cantidad de reoperaciones y al menos el $20 \%$ de los pacientes eventualmente tendrán una colostomía. Por lo tanto, la selección cuidadosa del paciente y la participación de los pacientes en la toma de decisiones con respecto a los posibles beneficios y limitaciones de esta técnica es primordial. Consulte Video Resumen en http://links.lww. com/DCR/B242. (Traducción-Dr. Gonzalo Hagerman)

KEY WORDS: Artificial bowel sphincter; Complication; Fecal incontinence; Follow-up; Long-term; Reoperation.

$\mathrm{F}$ ecal incontinence (FI), defined as the involuntary or uncontrolled loss of solid or liquid stool, is a common condition with a reported community prevalence ranging from $2 \%$ to $21 \%$ (median $7.7 \%$ ). ${ }^{1}$ It usually results from an interaction of multiple mechanisms, including stool consistency, sphincter weakness, loss of sensation, and impaired distension compliance of the rectum. These may be the result of obstetric or surgical injury, inflammation or irradiation, and aggravated by aging. ${ }^{2}$ Fecal incontinence strongly impairs quality of life by interfering with daily activities and by causing em- barrassment, depression, and social isolation. ${ }^{3,4} \mathrm{~A}$ combination of dietary and medical management and pelvic floor rehabilitation is recommended as first-line therapy for patients with FI. ${ }^{5}$

Nowadays, for patients not responding to either of these treatments, sacral neuromodulation (SNM) is a minimally invasive surgical option. In contrast to the minimally invasive surgical approach, more invasive surgical solutions such as the artificial bowel sphincter and dynamic graciloplasty (DGP) have previously been applied.

The artificial bowel sphincter (ABS) is usually reserved for patients with extensive sphincter destruction, congenital malformations, and neurogenic incontinence from spinal cord injury. ${ }^{5}$ The successful use of an ABS was first reported by Christiansen and Lorentzen ${ }^{6}$ in 1987. They used an artificial urinary sphincter in a patient with severe anal incontinence and myasthenia gravis who was reluctant to undergo a colostomy. Since then, several studies have been conducted, but with mixed results. ${ }^{7,8}$ From our own institute, we previously reported the results with ABS in a cohort of 33 patients with a mean follow-up of 17.4 months. ${ }^{9}$ In this study, we report our results with a larger cohort of 63 patients with extended follow-up of a median of 57 months.

\section{MATERIALS AND METHODS}

\section{Patient Selection}

The medical records of a consecutive cohort of patients who underwent an ABS implantation at Maastricht University Medical Center during the period from 1997 to 2014 were reviewed using standard forms. At the time of the treatment, ABS was considered as standard care in our hospital. Therefore, the medical ethics review committee concluded that the Medical Research Involving Human Subjects Act does not apply to this study. Oral informed consent was obtained from all patients after an explanation of the procedure and possible complications.

Preoperative examination consisted of defecography, endoanal ultrasound, and anal manometry. All patients underwent medical treatment and pelvic floor physiotherapy as a first treatment step. In case of sphincter defects of less than one-third of the circumference, the next step in the treatment algorithm was SNM. In case of large sphincter defects, patients were eligible for ABS. However, patients who had undergone SNM and DGP with unsatisfactory results were also eligible for ABS. This illustrates the severity of symptoms in this population with endstage severe FI. For many, ABS is considered as a last resort to avoid colostomy, at least for a period of time. Patients were not eligible for implantation of ABS in the case of a cloaca-like deformation or insufficient length of the perineum for adequate closing. 


\section{Surgical Procedure}

An Acticon ABS (American Medical Systems, Minneapolis, MN) was used in all patients. The surgical technique and implantation in our hospital has been described in detail previously. ${ }^{10}$ In brief, the ABS implant consists of an inflatable balloon, a cuff, and a pump. Thirty minutes before incision, systemic antibiotic prophylaxis is started and continued until 2 days postoperatively. Perioperatively, local antibiotics are administered in the wounds. The cuff is placed around the anus by using 2 lateral incisions. The size of the cuff is chosen based on circumferential length around the rectum and width. The pump is placed in the labium majus or scrotum, and the pressure-regulating balloon is placed in the cavum Retzii.

Initially, the device is left inactive after the operative procedure to allow the wound to heal. Patients are discharged after 3 to 4 days. After 4 weeks, the device is activated in the outpatient clinic and the patient receives instructions for proper use.

\section{Follow-up}

Patients had follow-up at 3, 6, and 12 months after implantation and yearly thereafter. At these visits, clinical evaluation was performed. Any additional treatment including the use of laxatives and bowel irrigation was recorded. Also, data on any reoperations were collected, including reason and type of operation.

The primary end point was any complication, according to Clavien-Dindo classification, ${ }^{11}$ including the frequency of the revisions of surgery due to device failure or infection. This end point was chosen because previous research and our own experience had already shown that ABS can be a beneficial treatment in some patients, but tends to be accompanied by major morbidity. Definite explantation and reimplantation were recorded as device revisions. When the removal of the device and the implantation of a new device were performed during the same procedure, this was considered as a single revision.

A secondary end point was fecal loss as judged by the patients. All patients were queried about the extent in which fecal continence was restored since implantation of the ABS, about sensation of opening and closing of the cuff, and about the presence of pain in the area of the ABS. In case of persisting symptoms, proper functioning of the device was assessed by digitation.

\section{Statistics}

Descriptive statistics were used to characterize the patient population in terms of age, sex, and etiology. Kaplan-Meier survival analyses were used to calculate proportions of patients who remained event-free over time. A separate analysis was conducted with colostomy formation as the end point. Explorative subgroup analyses were conducted for patients with an obstetric etiology of FI. All analyses were conducted using SPSS version 2.1.

\begin{tabular}{lc} 
TABLE 1. Outcomes after ABS & \\
Outcomes & No. of patients \\
\hline Restored continence & 15 \\
With ABS alone & 4 \\
Constipation treated with bowel irrigation & 2 \\
Constipation treated with laxatives & 1 \\
After ABS explantation & \\
Persistent incontinence with ABS & 4 \\
With ABS alone & 7 \\
With bowel irrigation & 8 \\
No ABS in situ with no further treatment & 4 \\
Dynamic graciloplasty & 9 \\
Colostomy & 9 \\
Lost to follow-up & $\mathbf{6 3}$ \\
Total &
\end{tabular}

$\mathrm{ABS}=$ artificial bowel sphincter.

\section{RESULTS}

\section{Demographics, Etiology, and Prior Surgical Treatment for FI}

Sixty-three patients had an ABS implanted at our center between April 1997 and November 2013 and were included in this study. Fifteen were male $(23.8 \%)$ and 48 were female (76.2\%); mean age at implantation was 54.8 years (range, 23-76). Median follow-up was 57 months (range, 1-198). Nine patients $(14.3 \%)$ were lost to follow-up (Table 1).

All patients experienced FI resistant to previous treatment. In most patients, FI originated from obstetric trauma (41 patients, $65.1 \%$ ); in 7 patients the incontinence had a congenital origin, 6 patients had exogenous pelvic floor trauma, and 9 patients had symptoms of an iatrogenic origin (in 7 patients, resulting from surgery; in 2 patients, resulting from a combination of surgery and radiotherapy). Thirty-nine patients $(61.9 \%)$ had previous surgical treatment: 17 (43.6\%) patients had SNM, 10 (25.6\%) had anal repair, 3 (7.7\%) had DGP. One (2.7\%) had anal repair and DGP, 7 (17.9\%) had anal repair and SNM, and $1(2.7 \%)$ had DGP and SNM.

\section{Revisions}

Figure 1 shows a graphic overview of the number and types of reoperation and the distribution of the patients within the cohort. The flow chart in Figure 2 shows the numbers of patients receiving 1 up to 6 reoperations. From the total cohort of 63 patients, 12 patients $(19.0 \%$, with mean follow-up of 43.4 months) had no reoperation. Of the 51 first reoperations, 31 patients had the device revised, in 17 patients the ABS was removed, and 3 patients had a colostomy. In 3 patients, a new ABS was implanted. A total of 46 patients still had an ABS in situ after the first reoperation $(63-3-17+3)$. A revision could consist of the proper placement of the cuff or the pressure balloon, reconnection of the tubes, and replacement of one or more parts of the device, for example a leaking cuff. 


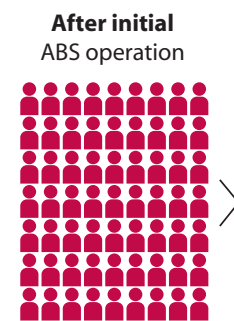

ABS in situ $(N=63)$

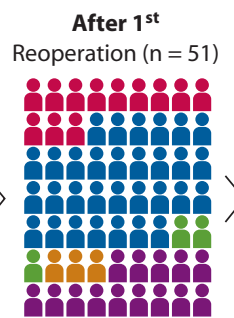

ABS in situ $(\mathrm{N}=46)$
After $2^{\text {nd }}$

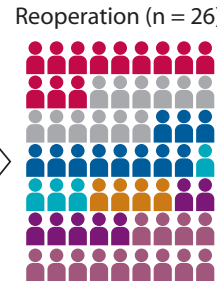

ABS in situ $(\mathrm{N}=39)$
After $3^{\text {rd }}$

Reoperation $(n=12)$

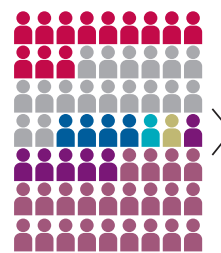

ABS in situ ( $N=35)$
After $4^{\text {th }}$

Reoperation $(n=6)$

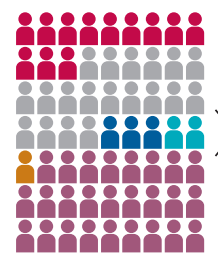

ABS in situ ( $N=36)$
After $5^{\text {th }}$

Reoperation $(n=4)$

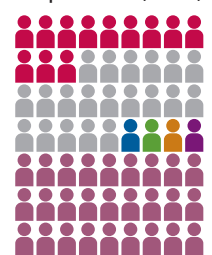

ABS in situ ( $N=34)$
After $6^{\text {th }}$

Reoperation $(n=2)$

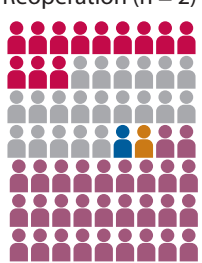

ABS in situ $(N=33)$

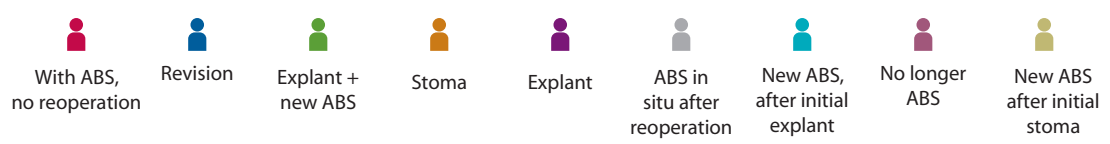

FIGURE 1. Overview of the number of reoperations ( $n$ ), specified by type. Revision is the reoperation on the ABS device in situ, possibly with replacement of some parts. Explant + new ABS is the explantation of ABS and implantation of new ABS in 1 session. Stoma is the explantation of $A B S$ and creation of a permanent stoma. Explant is the explantation of ABS. New ABS, after the initial explantation is the implantation of a new $A B S$ after a previous $A B S$ has been removed. $A B S=$ artificial bowel sphincter; $n=$ number of reoperations performed; $N=$ number of patients who still have active ABS.

Most patients had 1 reoperation (25 patients, $39.7 \%)$ $14(20.6 \%)$ had 2 reoperations, $6(9.5 \%)$ had 3 reoperations, $2(3.2 \%)$ had 4 reoperations, $2(3.2 \%)$ had 5 reoperations, and $2(3.2 \%)$ had 6 reoperations. In total, 101 reoperations were performed. Indications for reoperation were device failure $(51.7 \%)$, infection $(29.2 \%)$, recurrence of symptoms without signs of device failure (9.0\%), constipation $(2.2 \%)$, and pain (6.7\%).

\section{Perioperative Surgical Complications}

In 1 patient, the rectum was perforated during the placement of the cuff. The procedure was discontinued and the device was not implanted. A temporary ileostomy was created, and, after the perforation had healed, in a second attempt, the ABS was implanted.

\section{Outcomes of ABS}

Table 1 shows the functional outcomes of ABS in this cohort. Twenty-two $(34.9 \%)$ patients had restored continence. However, 2 of these patients used laxatives to treat constipation that developed after the ABS implant, and 1 patient remained continent after ABS explantation. Another 4 patients experienced such severe constipation after ABS implantation that retrograde bowel irrigation was needed. Eleven patients had persistent incontinence after ABS, of which 7 patients used bowel irrigation to treat symptoms.

In 31 patients $(49.2 \%)$ the device was explanted. In 1 additional patient, the device was explanted because the rectum was perforated perioperatively, and, after a discussion with the patient, a permanent stoma was created. Of these 31 patients, 12 did have a new ABS implanted at some point.

Reasons for removal of the ABS were infection $(n=21)$, device failure $(n=2)$, recurrent symptoms of FI $(n=5)$, pain $(\mathrm{n}=2)$, and constipation $(\mathrm{n}=1)$. After removal of the device, 9 patients had colostomy (apart from the 1 patient mentioned above) and 4 had a DGP (Table 1). Five of these patients with explanted ABS performed retrograde washouts to treat the FI; in 2 patients, symptoms had resolved, and 1 patient was treated conservatively.

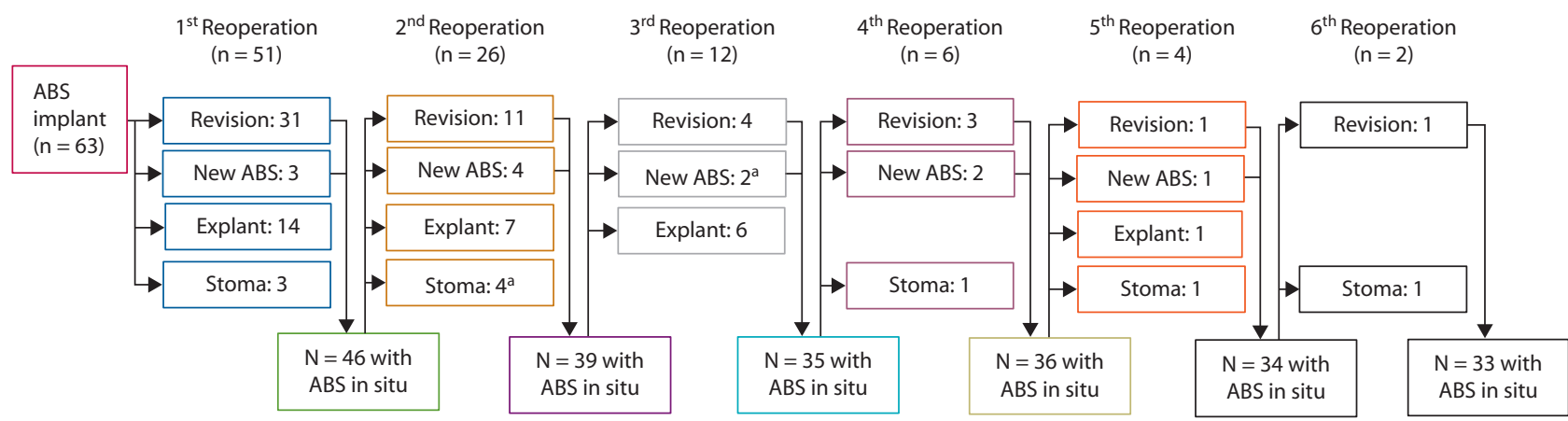

FIGURE 2. Flow chart of reoperations and number of patients. New ABS is the implantation of a new ABS after a previous ABS has been removed. Explant is the explantation of $A B S$. ${ }^{a}$ One of these patients with a stoma did eventually have a new $A B S$ implanted, registered under $3 r d$ reoperation. $A B S=$ artificial bowel sphincter; $n=$ number of reoperations performed; $N=$ number of patients who still have active $A B S$. 
Cumulative survival

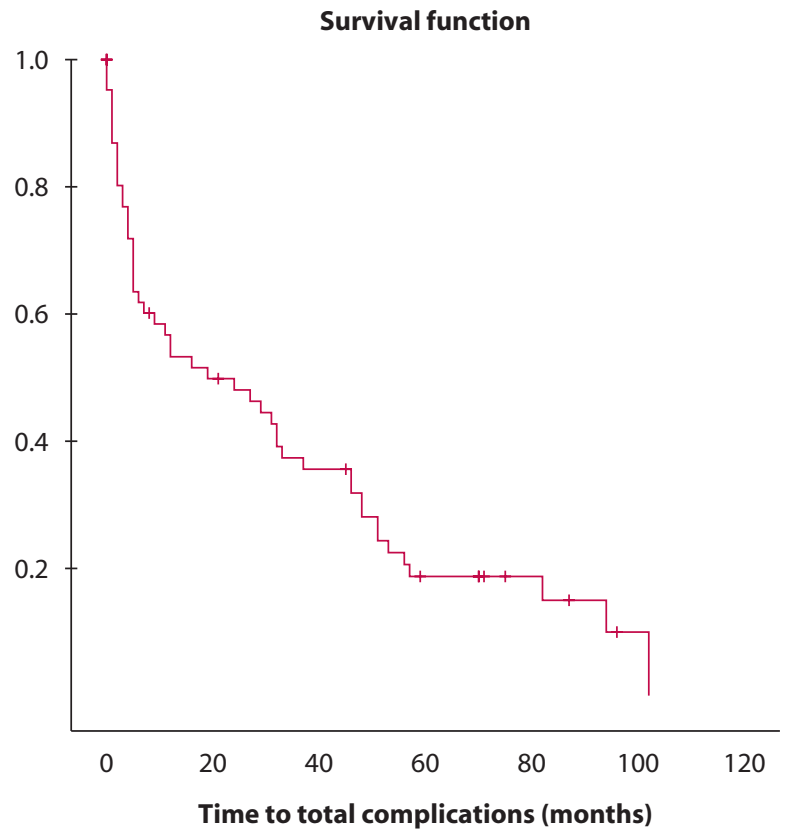

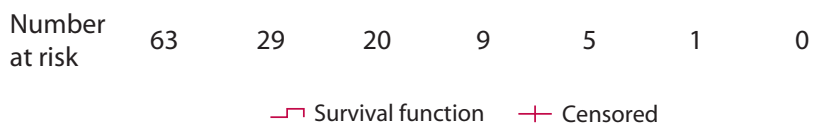

FIGURE 3. Kaplan-Meier curve. Time to event; event defined as any complication requiring surgery.

\section{Survival Analysis}

Figure 3 shows the results of the survival analysis with "complication requiring surgery" as the end point. This included complications requiring revision of the device, explantation of the device, either or not followed by colostomy or implantation of a second device. The results show that, at 5 years follow-up, approximately $80 \%$ of the cohort underwent surgery for this indication. In Figure 4, the results of the survival analysis for the end point colostomy are shown. After 5 years of follow-up, 18\% of the patients in the cohort underwent a colostomy. Figures 5 and 6 show the results of subgroup analyses for obstetric versus other etiologies. The subgroup of patients with obstetrical etiology fared better than the other patients in terms of complications requiring surgical revision and explantation of the device.

\section{DISCUSSION}

The key finding of this study is that our long-term results with $\mathrm{ABS}$ in the treatment of FI were considerably poorer than initially expected. A drawback of this study is its retrospective design. This also resulted in the fact that no consistent and objective outcome parameter was used to assess secondary outcome, fecal loss.

The outcome parameters as described in Materials and Methods illustrate one of the problems encountered with the technique of the ABS. Being a rather static solu-

\section{Cumulative survival}

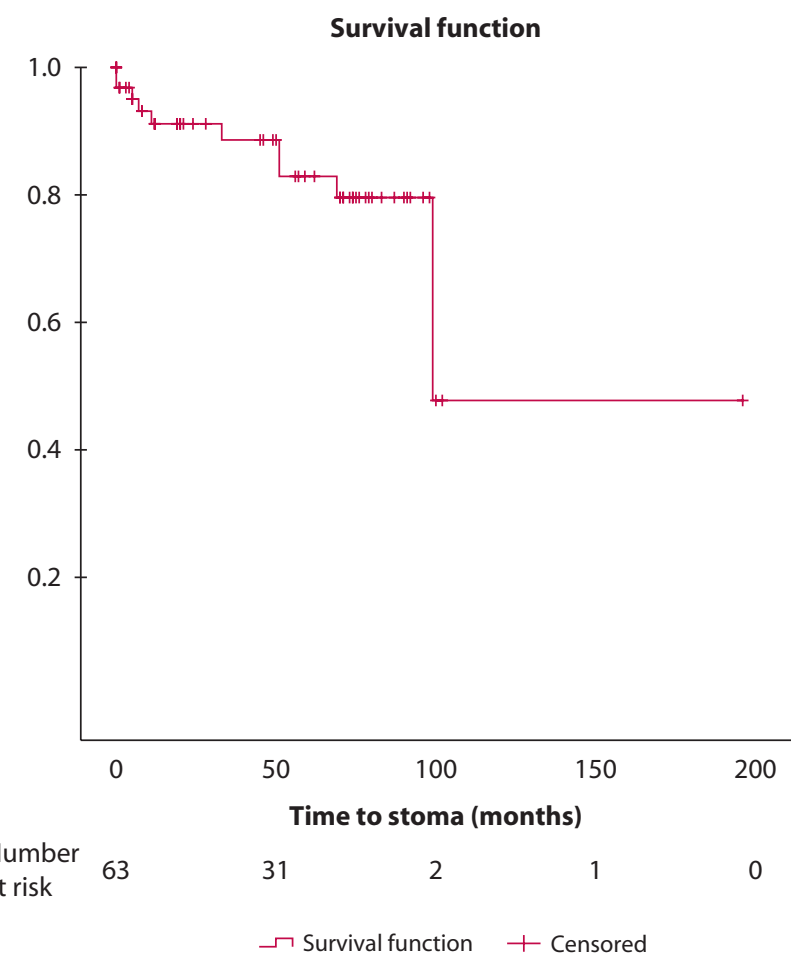

FIGURE 4. Kaplan-Meier curve. Time to event; event defined as formation of colostomy.

tion to a dynamic process, the ABS has to be able to close firmly enough to prevent incontinence, but also be able to open properly to facilitate defecation. In case of the recurrence of symptoms, the cause can be a technical problem, such as dislocation of the cuff or leakage of the ABS system. In some cases, this can be confirmed by digital examination or X-ray. When this appears not to be the case, recurrence might be caused by other factors influencing these symptoms, such as stool consistency or pelvic floor function. Being one of the last treatment options for these patients, in many cases, a pragmatic choice is a revision of the ABS system to pursue the improvement of symptoms. This leads to the situation of "recurrence of symptoms without signs of device failure," in which ultimately could be opted to a revision of the ABS anyway. This revision could include implantation of a smaller cuff or just proper positioning of the cuff. From the current cohort, exact data on the extent of each revision (if for example only cuff or balloon was replaced) are unfortunately not available. Although this study focussed on the long-term results of ABS, Figure 3 illustrates how revisions occur over the entire period of follow-up. In this light, the study by Wexner et $\mathrm{al}^{12}$ provides interesting additional information, reporting on a group of 51 patients treated with ABS, of which $35.3 \%$ became infected in the early stage ( $<6$ weeks after implantation) and $5.9 \%$ in the late stage, but late-stage complications continued to increase with time. 
Cumulative survival

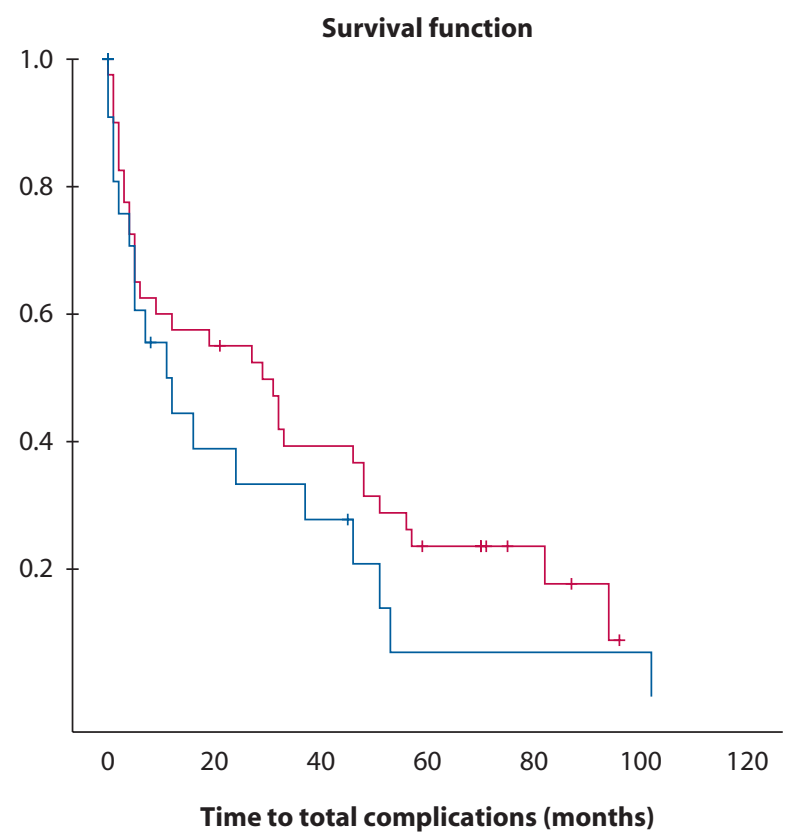

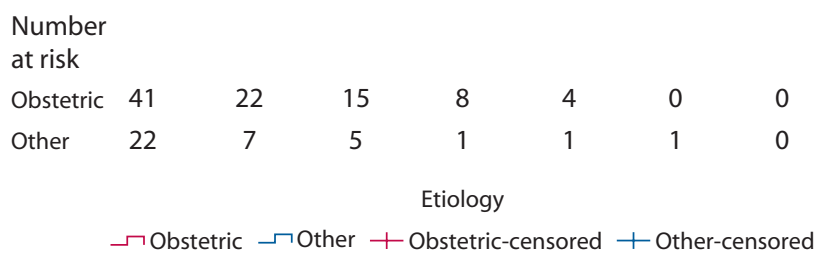

FIGURE 5. Kaplan-Meier curve. Time to event; event defined as any complication requiring surgery. Patients divided in 2 groups based on etiology obstetric versus other.

The technique of the implantation of the ABS is complex, with many different steps and meticulous maintenance of sterile conditions. Therefore, we have to consider the learning curve associated with this technique. This learning curve could be assessed by comparison of groups from different time periods. However, this goes beyond the scope of this study, and the number of patients in this study would be insufficient for such analysis. Next to technique, patient selection is probably of major impact on success rates as well. In our current cohort, a few oncological patients are included. Some underwent radiotherapy that may cause scarring and may augment surgical complications. Therefore, the risk of infection is probably increased on top of the innate problem of implanting prosthetic material in the anorectal region. Also, the previous treatments for FI, including DGP, illustrate the complexity of this group of patients. Patients are desperate to control FI, and $\mathrm{ABS}$ is often a last resort to avert colostomy. However, the results of this study and others suggest that the long-term outcomes of ABS are disappointing, making it uncertain whether it is truly beneficial to the patient. ${ }^{8}$ Moreover, it is questionable whether colostomy worsens patients' quality of life in the way and to the extent it is believed to do. In a Cochrane review, this traditional assumption is challenged

\section{Cumulative survival}

Survival function

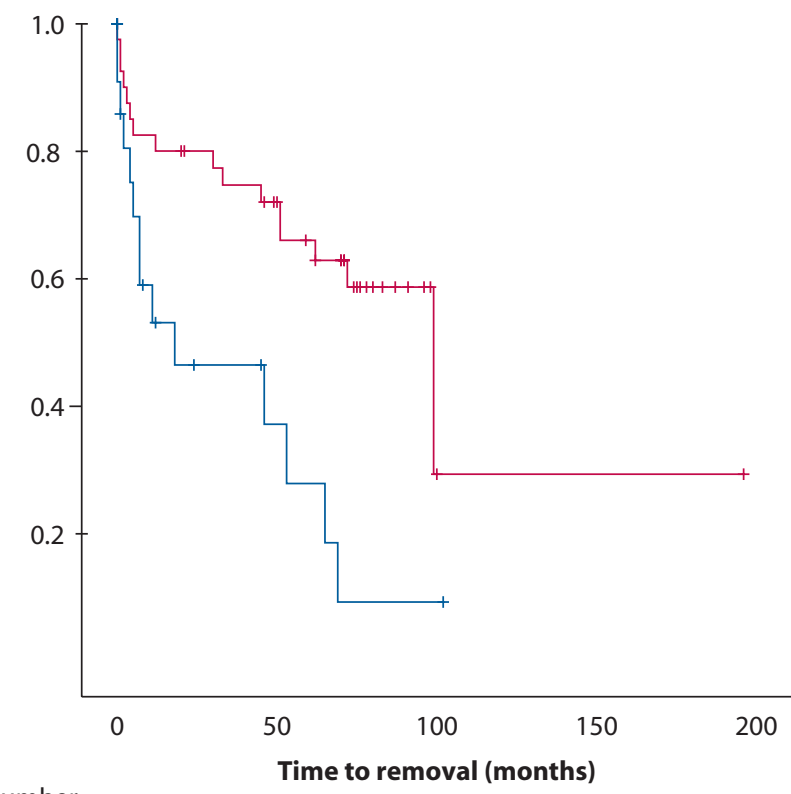

Number

at risk

$\begin{array}{lccccc}\text { Obstetric } & 41 & 24 & 1 & 1 & 0 \\ \text { Other } & 22 & 4 & 1 & 0 & 0 \\ & & & \text { Etiology }\end{array}$

$\neg$ Obstetric $\neg$ Other + Obstetric-censored + Other-censored

FIGURE 6. Kaplan-Meier curve. Time to event; event defined as explantation of the artificial bowel sphincter. Patients divided in 2 groups based on etiology obstetric versus other.

because 14 of 35 studies found no significant difference in quality of life between patients with or without a stoma after rectal cancer surgery. ${ }^{13}$

\section{Current Guidance in Need of Revision?}

According to the most recent guideline from the National Institute for Health Care and Excellence from 2012, patients with FI, in whom a trial of sacral nerve stimulation has been unsuccessful, can be considered for a neosphincter. ${ }^{14}$ Given the accumulating evidence of long-term complications associated with a neosphincter, these guidelines may be in need of revision. ${ }^{15}$ Because of our own experience with $A B S$, we decided that $A B S$ should no longer be offered to patients with FI. On top of that, the production of the device has ceased.

Another question is to what extent do we have to avoid creating a colostomy? According to the National Institute for Health Care and Excellence guideline, a colostomy is still seen as a last resort. It should only be considered if all nonsurgical and surgical options failed or were not indicated. However, the International Consultation on Incontinence guideline states, "Colostomy should not be regarded as a treatment failure but rather a reasonable treatment option for patients whose lives are restricted by fecal incontinence that is not amenable to other therapies or not 
suitable for more complicated surgical procedures." ${ }^{\prime 6}$ Data on the effectiveness, perioperative complications, and impact on the quality of life of colostomy for patients with FI are sparse, because colostomy is generally considered as a failure of treatment. The few primary studies available show positive results, and discussing the option of a colostomy with patients with FI is suggested. ${ }^{17,18}$ In the field of colorectal oncology, several studies showed that, in terms of quality of life, sphincter-preserving anterior resection is not necessarily superior to colostomy. ${ }^{13,19}$ Of course these results are dependent on population characteristics, pretreatment continence, level of the anastomosis, and use of questionnaires.

\section{Novel Approaches on the Horizon and Evidence Requirements}

In addition to lifestyle management, medical therapy, anal plug and anal insert device, physical therapy, SNM, posterior tibial nerve stimulation, and internal anal sphincter support, a number of innovative approaches to the treatment of FI are being developed. ${ }^{20-22}$ Novel treatment approaches include anorectal transplantation, ${ }^{23}$ biomemetic devices with sensory feedback, ${ }^{24}$ implantation of autologous myoblasts into the external anal sphincter, ${ }^{25}$ neurostimulated levator augmentation, ${ }^{26}$ and novel variants of the artificial anal sphincter. ${ }^{27-29}$ In addition, the magnetic anal sphincter is a new development with a mechanism of action similar to ABS. The initial results of the magnetic anal sphincter are promising, and it appears to be as effective as ABS and is associated with fewer complications. ${ }^{30,31}$ Unfortunately, it appears that this device is also currently off the market. ${ }^{32}$

Some of these new treatments are still of an experimental nature, and a major challenge will be to produce evidence of the safety and clinical- and cost-effectiveness of these innovations. The relevant question is whether such innovations should be preferred over colostomy. The most robust evidence to address this question would be derived from a randomized controlled trial, randomly allocating patients with FI refractory to colostomy or the innovative approach. However, producing evidence of the added value of these surgical innovations by conducting such trials unfortunately would be unethical and probably unfeasible or, at least, quite challenging.

\section{CONCLUSION}

The key finding of this study is that our long-term results with $\mathrm{ABS}$ in the treatment of FI were considerably poorer than initially expected. About one-third of patients had restored continence with ABS and approximately half of the patients will have a colostomy in the long term. Although some might still consider that this outcome justifies the operation, we need to take into account the very substantial number of complications requiring surgical interven- tion along the way. Therefore, careful patient selection and the involvement of patients in decision making regarding potential benefits and limitations of this technique are paramount.

\section{REFERENCES}

1. Ng KS, Sivakumaran Y, Nassar N, Gladman MA. Fecal incontinence: community prevalence and associated factors-a systematic review. Dis Colon Rectum. 2015;58:1194-1209.

2. Rao SS. Pathophysiology of adult fecal incontinence. Gastroenterology. 2004;126(1 suppl 1):S14-S22.

3. Visscher AP, Schuur D, Roos R, Van der Mijnsbrugge GJ, Meijerink WJ, Felt-Bersma RJ. Long-term follow-up after surgery for simple and complex cryptoglandular fistulas: fecal incontinence and impact on quality of life. Dis Colon Rectum. 2015;58:533-539.

4. Walter S, Hjortswang H, Holmgren K, Hallböök O. Association between bowel symptoms, symptom severity, and quality of life in Swedish patients with fecal incontinence. Scand J Gastroenterol. 2011;46:6-12.

5. Paquette IM, Varma MG, Kaiser AM, Steele SR, Rafferty JF. The American Society of Colon and Rectal Surgeons' clinical practice guideline for the treatment of fecal incontinence. Dis Colon Rectum. 2015;58:623-636.

6. Christiansen J, Lorentzen M. Implantation of artificial sphincter for anal incontinence. Lancet. 1987;2:244-245.

7. Hong KD, Dasilva G, Kalaskar SN, Chong Y, Wexner SD. Longterm outcomes of artificial bowel sphincter for fecal incontinence: a systematic review and meta-analysis. J Am Coll Surg. 2013;217:718-725.

8. Mundy L, Merlin TL, Maddern GJ, Hiller JE. Systematic review of safety and effectiveness of an artificial bowel sphincter for faecal incontinence. Br J Surg. 2004;91:665-672.

9. Melenhorst J, Koch SM, van Gemert WG, Baeten CG. The artificial bowel sphincter for faecal incontinence: a single centre study. Int J Colorectal Dis. 2008;23:107-111.

10. Wong WD, Congliosi SM, Spencer MP, et al. The safety and efficacy of the artificial bowel sphincter for fecal incontinence: results from a multicenter cohort study. Dis Colon Rectum. 2002;45:1139-1153.

11. Dindo D, Demartines N, Clavien PA. Classification of surgical complications: a new proposal with evaluation in a cohort of 6336 patients and results of a survey. Ann Surg. 2004;240:205-213.

12. Wexner SD, Jin HY, Weiss EG, Nogueras JJ, Li VK. Factors associated with failure of the artificial bowel sphincter: a study of over 50 cases from Cleveland Clinic Florida. Dis Colon Rectum. 2009;52:1550-1557.

13. Pachler J, Wille-Jørgensen P. Quality of life after rectal resection for cancer, with or without permanent colostomy. Cochrane Database Syst Rev. 2012;12:CD004323.

14. NICE (National Institute for Health and Care Excellence). Faecal incontinence in adults: management. NICE guidelines [CG49]. June 27, 2007. Available from https://www.nice.org.uk/ guidance/cg49/chapter/1-Guidance - surgery Accessed on February 2,2020

15. NICE (National Institute for Health and Care Excellence). Artificial anal sphincter implantation; NICE Interventional Procedure Guidance [IPG66]. June 23, 2004. Available from https:// 
http://www.nice.org.uk/guidance/ipg66/chapter/2-The-procedure. Accessed on February 2, 2020.

16. Abrams P, Cardozo L, Wagg A, Wein A, eds. Incontinence. 6th ed. Bristol, UK: ICI-ICS. International Continence Society; 2017. ISBN: 978-0956960733.

17. Colquhoun P, Kaiser R Jr, Efron J, et al. Is the quality of life better in patients with colostomy than patients with fecal incontience? World J Surg. 2006;30:1925-1928.

18. Norton C, Burch J, Kamm MA. Patients' views of a colostomy for fecal incontinence. Dis Colon Rectum. 2005;48:1062-1069.

19. Kornmann VN, Walma MS, de Roos MA, Boerma D, van Westreenen HL. Quality of life after a low anterior resection for rectal cancer in elderly patients. Ann Coloproctol. 2016;32: 27-32.

20. Carter D. Conservative and novel treatment options for fecal incontinence. J Gastrointest Dig Syst. 2016;6:428-434.

21. Wexner SD. New surgical treatments for faecal incontinence. Colorectal Dis. 2016;18:935-936.

22. Rosenblatt P. New developments in therapies for fecal incontinence. Curr Opin Obstet Gynecol. 2015;27:353-358.

23. Galvao FH, Araki J, Seid VE, et al. Evidence that anorectal transplantation is the logical treatment for serious anorectal dysfunction and permanent colostomy. Transplant Proc. 2016;48:497-498.

24. Fattorini E, Brusa T, Gingert C, et al. Artificial muscle devices: innovations and prospects for fecal incontinence treatment. Ann Biomed Eng. 2016;44:1355-1369.
25. Romaniszyn M, Rozwadowska N, Malcher A, Kolanowski T, Walega P, Kurpisz M. Implantation of autologous muscle-derived stem cells in treatment of fecal incontinence: results of an experimental pilot study. Tech Coloproctol. 2015;19:685-696.

26. Isbert C, Schlegel N, Reibetanz J, et al. Neurostimulated levator augmentation-a new approach in restoring continence. Int J Colorectal Dis. 2015;30:505-512.

27. Ratto C, Donisi L, Litta F, Campennì P, Parello A. Implantation of SphinKeeper ${ }^{\mathrm{TM}}$ : a new artificial anal sphincter. Tech Coloproctol. 2016;20:59-66.

28. Ratto C, Buntzen S, Aigner F, et al. Multicentre observational study of the Gatekeeper for faecal incontinence. Br J Surg. 2016;103:290-299.

29. Kajbafzadeh AM, Kajbafzadeh M, Sabetkish S, Sabetkish N, Tavangar SM. Tissue-engineered external anal sphincter using autologous myogenic satellite cells and extracellular matrix: functional and histological studies. Ann Biomed Eng. 2016;44:1773-1784.

30. Barussaud ML, Mantoo S, Wyart V, Meurette G, Lehur PA. The magnetic anal sphincter in faecal incontinence: is initial success sustained over time? Colorectal Dis. 2013;15:1499-1503.

31. Wong MT, Meurette G, Stangherlin P, Lehur PA. The magnetic anal sphincter versus the artificial bowel sphincter: a comparison of 2 treatments for fecal incontinence. Dis Colon Rectum. 2011;54:773-779.

32. Ethicon. The Fenix continence restoration system. http://www. toraxmedical.com/fenix/. Accessed on February 2, 2020. 